\title{
REUSING OF GLASS POWDER AND INDUSTRIAL WASTE MATERIALS IN CONCRETE
}

\author{
Raghavendra K ${ }^{1}$, Virendra Kumara. K. $\mathbf{N}^{2}$ \\ ${ }^{1}$ Student, Civil Engineering Department, Vijaya Vittla Institute of Technology, Karnataka, India \\ ${ }^{2}$ Associate Professor and Head, Civil Engineering Department, Vijaya Vittla Institute of Technology, Karnataka, India
}

\begin{abstract}
A huge amount of concrete is consumed in the construction work. A good quality concrete is mixing of cement, fine and coarse aggregates, water and admixtures as needed to obtain an optimum quality and economy. In this study investigation were carried out on compressive strength, split tensile strength and water absorption of M-40 grade of concrete mixes with $20 \%$ constant replacement of waste glass powder in cement and partial replacement of waste foundry sand in fine aggregate. From the test results, strength are achieved very less on $7^{\text {th }}$ and $14^{\text {th }}$ das but it increases on the $28^{\text {th }}$ day. High strength values found at $40 \%$ replacement level in strength parameters.
\end{abstract}

Keywords: waste glass powder, waste foundry sand, eco-friendly, concrete mix.

\section{INTRODUCTION}

The most of developing countries are facing disposing of waste materials using for landfill, this causes environmental problems. Industrial waste is a byproduct from the production of (ferrous and non-ferrous) casting industries. Industrial wastes are more then 2-3 times reused and recycled in casting process, after that $25-30 \%$ losses its strength so that it is disposed to landfill.

The glass powder is generated by waste glasses. The waste glass powder is increases strength of concrete, because glass powder content high percentage of silica. The major disadvantage is the cracking and swelling due to alkali-silica reaction. So many reaches concluded that $20 \%$ replacement level achieved good strength. So in this investigation glass powder used as $20 \%$ constant replacement in cement and industrial waste material used as partial replacement such as $0 \%, 10 \%, 20 \%, 30 \%, 40 \%$ and $50 \%$ in fine aggregate in concrete by using M40 grade.

\subsection{Glass Powder}

Basically waste glass powder is made from the waste glass material that cannot be recycle or reuse due to the high cost of recycling. Waste glass powder is being used for land fill. Due to environmental problem, researches try to use the waste glass powder in to the concrete to create a new material to use in construction field. Researcher found that the main material composition of glass powder is silica which is a constituent of cement also. The use waste glass powder in concrete creates a problem due to Alkali-Silica reaction. The reaction between alkalis in ordinary Portland cement and silica in aggregates and waste glass powder form silica gel.

\subsection{Industrial Waste Material}

Used foundry sand (UFS) is a waste material, comes from ferrous and non-ferrous metal cast industries. The metal cast industries yearly use an approximate 100 million tons of foundry sand for manufacture. This foundry sand is been recycled and reused the sand several times, due to this reason reduction in strength about $25 \%$ to $30 \%$. It is then removed as waste material in foundry industries. The disposed waste foundry sand is then used for land filling. There are two types of foundry sand i.e. Green sand (clay bonded system) and chemical bonded sand.

\section{EXPERIMENTAL MATERIALS}

\subsection{Cement}

The OPC 53 grade Birla super cement is used in this investigation and physical properties of cement are shown in table 1 .

Table-1: Physical Properties

\begin{tabular}{|l|l|}
\hline Properties & Results \\
\hline Specific Gravity & 3.14 \\
\hline Normal Consistency & $33 \%$ \\
\hline Final Testing Time & $260 \mathrm{~min}$ \\
\hline Initial Testing Time & $45 \mathrm{~min}$ \\
\hline Fineness Modulus & $5 \%$ \\
\hline
\end{tabular}

\subsection{Fine Aggregate}

Grading of fine aggregate are shown in Table 2.

Table-2: Grading of Fine Aggregate

\begin{tabular}{|l|l|l|l|l|l|}
\hline A & B & C & D & E & F \\
\hline $4.75 \mathrm{~mm}$ & 22 & 2.2 & 2.2 & 97.2 & $90-100$ \\
\hline $2.26 \mathrm{~mm}$ & 30 & 3 & 5.2 & 94.8 & $75-100$ \\
\hline $1.18 \mathrm{~mm}$ & 100 & 10 & 15.2 & 84.8 & $55-90$ \\
\hline
\end{tabular}




\begin{tabular}{|l|l|l|l|l|l|}
\hline $600 \mu$ & 250 & 25 & 40.2 & 59.8 & $35-59$ \\
\hline $300 \mu$ & 500 & 50 & 90.2 & 9.2 & $8-30$ \\
\hline $150 \mu$ & 72 & 7.2 & 97.2 & 2.6 & $0-10$ \\
\hline pan & 30 & 3 & 100 & - & - \\
\hline
\end{tabular}

Note: $\quad \mathrm{A}=\mathrm{IS}$ Sieve

$\mathrm{B}=$ Weight Retained in gms

$\mathrm{C}=\%$ Weight Retained

$\mathrm{D}=$ Cumulative $\%$ Weight retained

$\mathrm{E}=$ Cumulative $\%$ Passing

$\mathrm{F}=$ Standard Requirement for Zone II as Per IS 383:1970

\subsection{Coarse Aggregate}

In this investigation we have used $20 \mathrm{~mm}$ down size for coarse aggregates and they are tested as per IS 2386. The results are shown in table 3

Table 3: Sieve Analysis Test

\begin{tabular}{|l|l|l|l|l|l|}
\hline $\mathrm{M}$ & $\mathrm{N}$ & $\mathrm{O}$ & $\mathrm{P}$ & $\mathrm{Q}$ & $\mathrm{R}$ \\
\hline 1 & $20 \mathrm{~mm}$ & 120 & 2.4 & 2.4 & 97.6 \\
\hline 2 & $12.5 \mathrm{~mm}$ & 4418 & 88.36 & 90.76 & 9.24 \\
\hline 3 & $10 \mathrm{~mm}$ & 404 & 8.08 & 98.84 & 2.26 \\
\hline 4 & $4.75 \mathrm{~mm}$ & 50 & 1 & 99.84 & 0.26 \\
\hline 5 & Pan & - & - & & - \\
\hline
\end{tabular}

Note: $\quad \mathrm{M}=\mathrm{S} 1$. No.

$\mathrm{N}=$ IS Sieve

$\mathrm{O}=$ Weight Retained in gms

$\mathrm{P}=\%$ Weight Retained

$\mathrm{Q}=$ Cumulative $\%$ Weight Retained

$\mathrm{R}=$ Cumulative $\%$ Passing

\subsection{Industrial Waste Material}

Physical properties of Industrial waste material shown in Table 5

Table-5: Physical Properties

\begin{tabular}{|l|l|}
\hline Property & result \\
\hline Specific property & 2.75 \\
\hline Water absorption & $0.45 \%$ \\
\hline Moisture content & $0.1 \%$ \\
\hline Fineness Modulus & 2.74 \\
\hline
\end{tabular}

\subsection{Glass Powder}

Physical properties of glass powder shown in table 4

Table-4: Physical Properties

\begin{tabular}{|l|l|}
\hline $\begin{array}{l}\text { Physical properties of glass } \\
\text { powder }\end{array}$ & Results \\
\hline Specific gravity & 2.73 \\
\hline Median particle size $(\mu)$ & $90 \mu$ \\
\hline Moisture content $(\%)$ & $0.1 \%$ \\
\hline
\end{tabular}

\section{RESULT AND DISCUSSIONS}

\subsection{Compressive Strength Test}

The compressive strength test was carried out on cube specimens of $150 \times 150 \times 150 \mathrm{~mm}$ size prepared in accordance with I.S: $516-1959$ at 7,14 and 28 days using compression testing machine. The details of the seven different specimens are as given in Table 6 and chart 1

Table-6: Compressive strength Values

\begin{tabular}{|l|l|l|l|}
\hline $\begin{array}{l}\text { Mix } \\
\text { Designation }\end{array}$ & 7 days & 14 days & 28 days \\
\hline CC & 26.31 & 39.47 & 43.86 \\
\hline A0 & 26.47 & 39.71 & 44.13 \\
\hline A10 & 28.86 & 41.22 & 45.81 \\
\hline A20 & 30.03 & 43.64 & 48.49 \\
\hline A30 & 35.36 & 47.51 & 52.79 \\
\hline A40 & 36.51 & 50.55 & 56.17 \\
\hline A50 & 31.27 & 46.90 & 52.12 \\
\hline
\end{tabular}

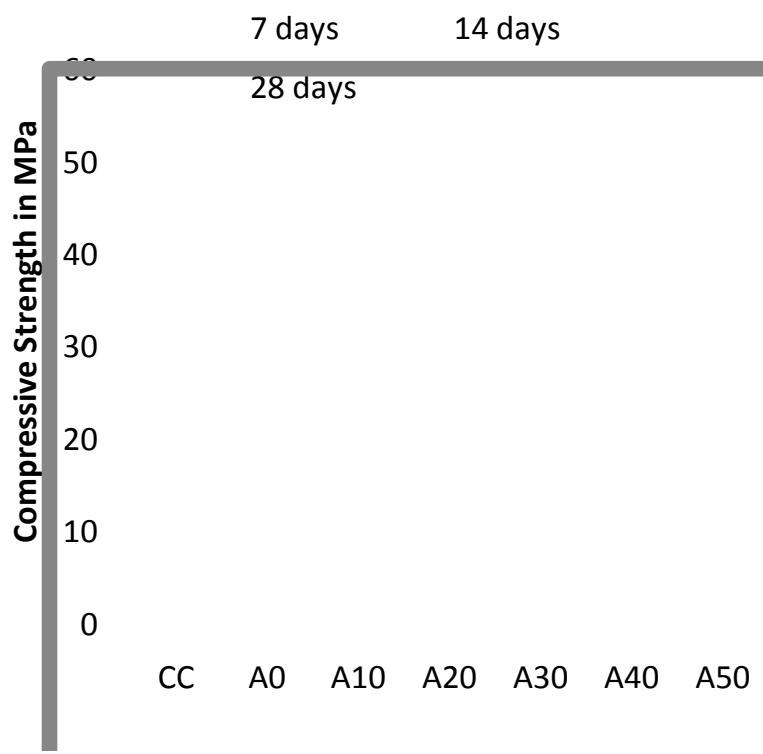

Chart-1: Compressive Strength Values

Note:

$\mathrm{CC}=$ Conventional Concrete

A0 $=20 \%$ Glass Powder $+0 \%$ Industrial waste

A $10=20 \%$ Glass Powder $+10 \%$ Industrial waste

A20 $=20 \%$ Glass Powder $+20 \%$ Industrial waste

$\mathrm{A} 30=20 \%$ Glass Powder $+30 \%$ Industrial waste

$\mathrm{A} 40=20 \%$ Glass Powder $+40 \%$ Industrial waste

A50 $=20 \%$ Glass Powder $+50 \%$ Industrial waste

\subsection{Split Tensile Strength}

The test results of split tensile test are as shown in Table 6 . Fig 2 shows the variation of split tensile strength with various curing periods. It can be see that the split tensile strength of concrete at 7, 14 and 28 days increases initially as the percentage of replacement of waste glass powder and waste foundry sand increases and becomes maximum at a percentage around A40. 
Table-7: Split Tensile Strength Values

\begin{tabular}{|l|l|l|l|}
\hline $\begin{array}{l}\text { Mix } \\
\text { Designation }\end{array}$ & 7 days & 14 days & 28 days \\
\hline CC & 2.55 & 3.67 & 4.16 \\
\hline A0 & 2.27 & 3.77 & 4.28 \\
\hline A10 & 2.95 & 3.91 & 4.21 \\
\hline A20 & 2.83 & 4.69 & 4.53 \\
\hline A30 & 3.62 & 4.65 & 5.42 \\
\hline A40 & 3.73 & 4.81 & 5.86 \\
\hline A50 & 2.97 & 4.41 & 4.82 \\
\hline
\end{tabular}

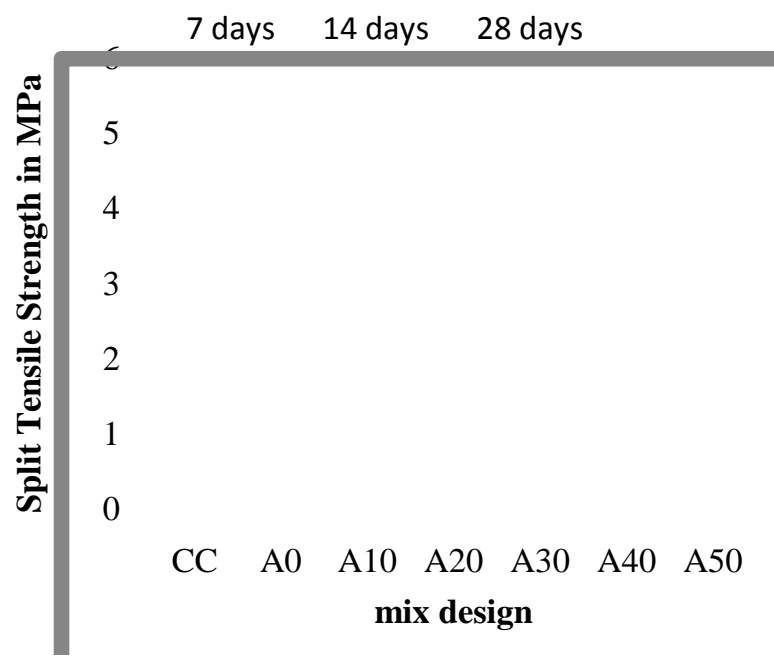

Chart-2: Split Tensile Strength Values

\subsection{Water Absorption Test}

The test results of water absorption test are as shown in Table 8 shows the variation of water absorption of different mix designations. It is seen from the water absorption test, as the percentage of replacement of waste glass powder and waste foundry sand increases, the water absorption ability of the specimen decreases and becomes least at a percentage around A50. So it can be said that, the concrete at A50 replacement level is durable against water absorption.

Table-8: Water Absorption Test

\begin{tabular}{|l|l|}
\hline Mix Design & 28 Days \\
\hline CC & 2.2 \\
\hline A 0 & 2.0 \\
\hline A 10 & 2.0 \\
\hline A 20 & 1.9 \\
\hline A 30 & 1.7 \\
\hline A 40 & 1.6 \\
\hline A 50 & 1.5 \\
\hline
\end{tabular}

\section{CONCLUSION}

Paragraph comes content here. Paragraph comes content On the basis of experimental study in the form of strength and durability tests by constant replacement $(20 \%)$ using waste glass powder as cement and partial replacement (i.e.0\%, $10 \%, 20 \%, 30 \%, 40 \%$ and $50 \%$ ) as natural fine aggregate. the production of concrete, the following conclusions are drawn:

1. The compressive strength of concrete at 7, 14 and 28 days increases initially as the percentage of replacement of waste glass powder and waste foundry sand increases and becomes maximum at a proportion around A40.

2. The split tensile strength of concrete at 7, 14 and 28 days increases initially as the percentage of replacement of waste glass powder and waste foundry sand increases and becomes maximum at a proportion around A40.

3. The water absorption of concrete at 28 days decreases gradually as the percentage of waste glass powder and waste foundry sand increases and becomes least at a proportion around A50.

4. Optimum replacement level for waste glass powder and waste foundry sand in place of ordinary Portland cement and natural fine aggregate respectively is found to be proportion of A40 from the consideration of strength and durability tests of concrete.

\section{ACKNOWLEDGEMENTS}

The authors thankfully acknowledge to Dr. S. B. Anadinni, Prof. Parvathy Sankar their motivational support to carry out this research work.

\section{REFERENCES}

[1]. Tiwari Darshit,"Study of Strength and Workability of Different Grades of Concrete by Partial Replacement of Fine Aggregate by Crushed Brick and Recycled Glass Powder" , International Journals of Science and Research (IJSR), Impact factor (2012):3.358.

[2]. Jitendra Bjangi,"Experimental Investigation of Waste Glass Powder as the Partial Replacement of Cement in Concrete Production", Journal of Mechanical and Civil Engineering (IOSR-JMCE), e-ISSN:2278-1684,pp.55-60.

[3]. Gunalaan Vasudevan," Performance of Using Waste Glass Powder in Concrete as Replacement of Cement", American Journals of Engineering Research (AJER),ISSN:2320-0847, Vol. 02, pp.175-181, 2013.

[4]. Dr.G.Vijaykumar," Studies on Glass Powder as Partial Replacement of Cement In Concrete Production", International journal of engineering technology advanced engineering, Vol.3, Issue 2, Feb 2013. 